\title{
MPZL1 Gene
}

National Cancer Institute

\section{Source}

National Cancer Institute. MPZL1 Gene. NCI Thesaurus. Code C24612.

This gene plays a role in cell migration. 